\title{
Lifestyle Habits of People with Self-Reported Diabetes: Changes during a Five-Year Period
}

\author{
Mario Šekerija ${ }^{1}$, Tamara Poljičanin ${ }^{2}$ and Željko Metelko ${ }^{2,3}$ \\ ${ }^{1}$ Croatian National Institute of Public Health, Zagreb, Croatia \\ ${ }^{2}$ University of Zagreb, Merkur University Hospital, Vuk Vrhovac University Clinic, Zagreb, Croatia \\ ${ }^{3}$ University of Zagreb, School of Medicine, Zagreb, Croatia
}

\begin{abstract}
A B S T R A C T
The aims of our study were to investigate the prevalence of risk factors in persons with previously known diabetes (»old DM"), persons with diabetes developed during the 2003-2008 period (»new DM") and diabetes-free individuals within the CroHort study. Risk factors were defined as physical inactivity, unhealthy nutritional regimen, smoking and excessive alcohol consumption, while diabetes status was self-reported. The most prevalent risk factor in both "old DM " and "new DM" group was physical inactivity (46.7\% and 33.7\% in 2003; $46.8 \%$ and $46.3 \%$ in 2008), then smoking (12.1\% and $14.6 \% ; 12.7 \%$ and $14.4 \%)$, unhealthy diet (8.8\% and 13.8; $8.2 \%$ and $10.0 \%$ ) and heavy alcohol consumption (11.1\% and $6.0 \% ; 7.8 \%$ and $13.8 \%$ ). Diabetes-free individuals had higher rates of smoking and unhealthy diet, and lower rates of alcohol consumption and physical inactivity than both diabetes groups. These results indicate the need for comprehensive actions oriented towards persons with diabetes concerning physical activity.
\end{abstract}

Key words: diabetes mellitus, physical activity, smoking, alcohol consumption, nutrition, CroHort study

\section{Introduction}

The worldwide estimates of the prevalence of diabetes mellitus suggest that 285 million persons suffered from diabetes in 2010, while the number of persons living with diabetes or impaired glucose tolerance will surpass 900 million by the year $2030^{1}$. Type 2 diabetes, a disease largely preventable by behavioural changes in physical activity $^{2}$ and diet $^{3}$, constitutes the vast majority (>90\%) of these cases. Urbanization, especially in developing countries, is characterized by the relocation of large portions of the rural population to urban areas, as well as lifestyle and dietary changes, and can be linked to the increasing prevalence of both obesity and diabetes ${ }^{4}$.

Obesity and physical inactivity are considered the key risk factors in the development of type 2 diabetes mellitus $^{5}$. Obesity is associated with insulin resistance, $\beta$ cell expansion, and hyperinsulinemia, ultimately leading to diabetes devolopment ${ }^{6}$. Physical inactivity is also associated with higher risks of developing diabetes ${ }^{7}$, even after controlling for $\mathrm{BMI}^{8}$. Types of diet have also been often studied as risk factors for diabetes; for example, it has been demonstrated that an increased intake of sugary drinks contributes to elevated risks of developing type 2 diabetes and metabolic syndrome ${ }^{9}$. Smoking is an additional risk factor for elevated insulin resistance ${ }^{10}$, hyperinsulinemia and relative glucose intolerance ${ }^{11}$. Alcohol consumption has an U-shaped relationship to diabetes, where diabetes is less common in persons who consume moderate amounts of alcohol than in teetotallers and alcohol abusers ${ }^{12}$.

These factors, aside from playing a role in the development of diabetes, are also important factors in its metabolic regulation. Obesity can influence the course of diabetes ${ }^{13}$, and the improvement in above parameters reduces the risk of both micro- and macrovascular complications and that of cardiovascular and all-cause mortality ${ }^{14,15}$. Although the guidelines of all major diabetological societies highlight the need for regular physical activity and a balanced diet ${ }^{16,17}$, epidemiological data suggest a high prevalence of unhealthy behaviours in persons with diabetes ${ }^{18,19}$.

It is estimated that there are 316000 diabetics in Croatia, with national prevalence in adults of $9.2 \%{ }^{20,21}$. Previous results indicate that compared to the persons 
without diabetes, diabetic persons in Croatia report better nutritional habits, they are less likely to be smokers or alcohol abusers, but more likely to be physically inactive $^{19}$. The aims of this paper were (a) to compare dietary habits, physical activity, smoking and alcohol use in 2008 between people who were already diagnosed with diabetes in 2003, those who developed it by 2008 and those who remained diabetes-free for the entire time, and (b) to compare the changes within these groups during the 2003-2008 period.

\section{Patients and Methods}

This study was a part of the Croatian Health Cohort Study (CroHort), a repeated cross-sectional survey of adults aimed at providing a comprehensive community health assessment of Croatians, including their access to and use of health care services, health status, and determinants of health such as nutrition, physical activity, smoking, and alcohol consumption. The complete design of the CroHort is described elsewhere ${ }^{22,23}$. In brief, a large field study designed to provide nearly complete coverage $(98 \%)$ of the Croatian adult population was performed in 2003, with a total of 9070 respondents aged 18 and over. The study was repeated in 2008 , with a cohort of 3229 respondents included in both survey waves. Because data on self-reported diabetes status were incomplete for 131 subjects, our study included data on a total of 3098 respondents.

Diabetes was assessed based on patients' self-reported medical history, i.e. answer to the question »Do you have elevated sugar?«. Participants in analysis were divided in three groups according to diabetes status (»old $\mathrm{DM} «$ - self-reported diabetes at baseline, »new $\mathrm{DM} «-$ diabetes-free at baseline, diabetes in 2008, and "no DM « free of diabetes at both occasions). The most important behavioural risk factors as assessed in our study were defined as follows ${ }^{24}$ :

\section{Unhealthy diet}

Subjects who reported three or more of the following risks were considered as having an unhealthy diet: consumption of animal fat, consumption of milk and milk products with more than $1.5 \%$ of fat, eating smoked meat products every day, not eating fruit every day, always adding salt to food.

\section{Physical inactivity}

Subjects who reported three or more of the following risk factors were considered as physically inactive: working at home, travelling to work by public transport, or working within a 15-min walking or cycling distance, easy or very easy job (sedentary or walking), physical activity less than 30 min a day during leisure time, advice received from a health care professional within the past year to increase physical activity.

\section{Smoking}

Subjects who reported never smoking, smoking only occasionally, or every day for up to 5 years, more than 10 years before the survey were not considered to be at risk, whereas those who reported regular smoking for at least 5 years in the previous 10-year-period were considered to be at risk.

\section{Alcohol consumption}

Subjects who reported drinking six or more glasses or bottles of alcohol on a single occasion, once a week or more often, or drinking every day and receiving advice from a family member or health care professional to drink less were considered to be at risk.

\section{Statistics}

Analysis was performed using SAS version 9.1.3.

Descriptive analysis included calculations of means and standard deviations. Prevalence of unhealthy diet, alcohol consumption, smoking and physical inactivity in 2003 and 2008 was compared between groups using $\chi^{2}$ test. Within-group differences in the prevalences of a particular habit in 2003 and 2008 investigated using McNemar's test. Differences in continuous variables among groups were investigated using ANOVA, with Scheffe post-hoc test where appropriate.

Statistical significance was set at $\alpha$ value of $5 \%$ in all analyses.

\section{Results}

At baseline, persons who will develop diabetes by 2008 (»new $\mathrm{DM}$ «) were older than persons who will remain diabetes-free (»no $\mathrm{DM} «)(\mathrm{p}<0.001$ for ANOVA, $\mathrm{p}=$ 0.001 , Scheffe's post hoc), and younger than those who already had diabetes (»old $\left.\mathrm{DM}_{«)}\right),(\mathrm{p}=0.001)$. The sex composition of the groups was also significantly different $(p=0.002$, chi square test). The »new $\mathrm{DM} «$ group had higher BMI and systolic blood pressure (SBP) (both p's $<0.001$, Scheffe's post hoc) and higher diastolic blood pressure $(\mathrm{DBP})(\mathrm{p}=0.001)$ than the $»$ no $\mathrm{DM}$ « group. The »new $\mathrm{DM}$ « and »old $\mathrm{DM}$ « group did not differ in BMI $(\mathrm{p}=0.401), \operatorname{SBP}(\mathrm{p}=0.052)$ and $\mathrm{DBP}(\mathrm{p}=0.987)$, while the »no DM « had significantly lower BMI, SBP and DBP than »old DM " group (all p's<0.001, Scheffe's post hoc). Prevalence of risky lifestyle habits differed significantly across groups, with the highest percentage of physically inactive $(46.7 \%)$ and those who consume alcohol excessively $(11.1 \%)$ in the »old $\mathrm{DM}$ « group, while the »no DM« group had the highest prevalence of unhealthy diet (15.4\%) and smoking (19.2\%).

At the 2008 follow-up, the »new $\mathrm{DM}$ « group had the highest BMI $(p<0.001$ for ANOVA, $p<0.001$ vs »no DM « and $p=0.009$ vs »old DM «; Scheffe's post hoc). Compared to »no $\mathrm{DM}$ «, the »new $\mathrm{DM}$ « group had higher SBP $(p<0.001)$, with no differences in DBP $(p=0.078)$. There were no differences in SBP $(p=0.853)$ and DBP $(p=$ 
TABLE 1

CHARACTERISTICS OF SUBJECTS WITHOUT A HISTORY OF DIABETES MELLITUS, WITH DIABETES MELLITUS ALREADY DIAGNOSED IN 2003 AND THOSE DIAGNOSED IN 2008

\begin{tabular}{|c|c|c|c|c|}
\hline & $\begin{array}{l}\text { Subjects without } \\
\text { a history of diabetes } \\
(\mathrm{N}=2461)\end{array}$ & $\begin{array}{l}\text { Subjects without diabetes } \\
\text { in } 2003 \text {, but with diabetes } \\
\text { in } 2008(\mathrm{~N}=261)\end{array}$ & $\begin{array}{c}\text { Subjects with } \\
\text { diabetes in } 2003 \\
(\mathrm{~N}=376)\end{array}$ & $\mathrm{p}^{*}$ \\
\hline Age/ years (in 2003) & $53.9 \pm 16.0$ & $58.5 \pm 13.0$ & $64.1 \pm 9.9$ & $<0.001$ \\
\hline Sex & & & & 0.002 \\
\hline Male & $30.3 \%$ & $35.2 \%$ & $38.6 \%$ & \\
\hline Female & $69.7 \%$ & $64.8 \%$ & $61.4 \%$ & \\
\hline Body mass index 2003 & $26.6 \pm 4.5$ & $29.2 \pm 4.8$ & $29.7 \pm 5.2$ & $<0.001$ \\
\hline Systolic blood pressure 2003 & $134.0 \pm 23.7$ & $141.5 \pm 23.1$ & $146.1 \pm 22.8$ & $<0.001$ \\
\hline Diastolic blood pressure 2003 & $80.8 \pm 12.2$ & $83.8 \pm 11.6$ & $83.6 \pm 11.1$ & $<0.001$ \\
\hline Unhealthy diet 2003 & $15.4 \%$ & $13.8 \%$ & $8.8 \%$ & 0.003 \\
\hline Physical inactivity 2003 & $31.9 \%$ & $33.7 \%$ & $46.7 \%$ & $<0.001$ \\
\hline Smoking 2003 & $19.2 \%$ & $14.6 \%$ & $12.1 \%$ & 0.001 \\
\hline Heavy alcohol consumption 2003 & $6.1 \%$ & $6.0 \%$ & $11.1 \%$ & 0.021 \\
\hline Body mass index 2008 & $27.6 \pm 5.1$ & $30.6 \pm 5.7$ & $29.3 \pm 5.4$ & $<0.001$ \\
\hline Systolic blood pressure 2008 & $134.0 \pm 20.3$ & $141.3 \pm 20.3$ & $142.3 \pm 20.9$ & $<0.001$ \\
\hline Diastolic blood pressure 2008 & $80.5 \pm 10.4$ & $82.1 \pm 10.8$ & $81.4 \pm 10.0$ & 0.039 \\
\hline Unhealthy diet 2008 & $12.9 \%$ & $10.0 \%$ & $8.2 \%$ & 0.019 \\
\hline Physical inactivity 2008 & $35.6 \%$ & $46.3 \%$ & $46.8 \%$ & $<0.001$ \\
\hline Smoking 2008 & $19.5 \%$ & $14.4 \%$ & $12.7 \%$ & 0.003 \\
\hline Heavy alcohol consumption 2008 & $7.0 \%$ & $13.8 \%$ & $7.8 \%$ & 0.021 \\
\hline
\end{tabular}

* ANOVA for continuous variables, and $\chi^{2}$-test for categorical variables

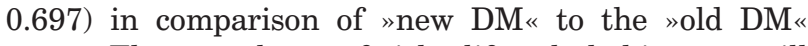
group. The prevalence of risky lifestyle habits was still significantly different across the groups.

The "new DM « and »no DM « groups had statistically significantly higher BMI in 2008 than in 2003 ( $p<0.001$; paired t-test), while the »old $\mathrm{DM}$ « group did not $(\mathrm{p}=$ 0.147). The "new $\mathrm{DM}$ « group had lower DBP in 2008 $(\mathrm{p}=0.042)$ with no changes in SBP $(\mathrm{p}=0.870)$, the $»$ old $\mathrm{DM}$ « group had lower SBP $(\mathrm{p}=0.006)$ and DBP $(\mathrm{p}=$ $0.001)$ in 2008 while the no $\mathrm{DM}$ « group had no changes in SBP $(p=0.810)$ and DBP $(p=0.217)$. The results are presented in Table 1.

When comparing the changes in prevalence of risky lifestyle habits within groups throughout the study, significant differences were seen in the "no $\mathrm{DM}$ « group for unhealthy diet (15.4\% in 2003 and $12.9 \%$ in 2008; $\mathrm{p}=$ 0.008 , McNemar test), physical inactivity (31.7\% vs. $35.6 \% ; \mathrm{p}=0.001)$ and heavy alcohol consumption $(6.6 \%$ vs. $8.5 \% ; \mathrm{p}=0.035$ ), while the $»$ new DM group « had statistically significant differences in prevalence of physical inactivity ( 34.0 vs. $46.3 \%$; $\mathrm{p}=0.002$ ). The results are presented in Table 2.

The percentage of participants who had no risky lifestyle habits at baseline was highest in »new DM « group $(50.0 \%)$, followed by »no $\mathrm{DM} «(43.9 \%)$ and »old $\mathrm{DM}$ « (40.2\%), while in 2008 the highest proportion was observed in »no $\mathrm{DM} «(42.6 \%)$, followed by »old $\mathrm{DM} «(40.3 \%)$ and »new $\mathrm{DM}_{«}(36.9 \%)$. These results are presented in Table 3.

\section{Discussion and Conclusion}

The improvement in lifestyle habits, namely diet and physical activity can prevent or delay diabetes and its complications $\mathrm{s}^{2,25}$, and the adherence to healthy lifestyle habits is an important indicator of overall public health and can be used to predict both future health-related trend and associated economic $\operatorname{costs}^{26}$.

At baseline, persons who will develop diabetes by 2008 (»new $\mathrm{DM} «$ ) were older than persons who will remain diabetes free (»no $\mathrm{DM} \ll)$, and younger than those who already had diabetes (»old $\mathrm{DM} \ll$ ), this finding being in consistency with the fact that age is a recognized risk factor for development of diabetes. The observed higher percentage of males in the self-reported »new $\mathrm{DM}$ « and »old $\mathrm{DM}$ « groups in comparison to »no $\mathrm{DM}$ « is explained by higher prevalence of DM in males in Croatia, as reported before ${ }^{21}$.

The finding of higher BMI, SBP and DBP in »new $\mathrm{DM}$ « group in comparison to »no $\mathrm{DM}$ « suggests that, within the participants that did not have diabetes at baseline, higher age, elevated BMI, systolic and diastolic blood pressure could be possible markers of higher risk for development of diabetes, which is in consistency with previous research ${ }^{27}$

Our previous study ${ }^{19}$ has pointed to the high prevalence of physical inactivity in diabetic individuals. The results shown in this study indicate that, in persons who developed diabetes during the 5-year follow-up period of 
TABLE 2

CHANGES IN PREVALENCE OF UNHEALTHY HABITS WITHIN DIABETES-RELATED GROUPS, 2003-2008*

\begin{tabular}{|c|c|c|c|c|c|}
\hline & & $2003(\%)$ & $2008(\%)$ & $\mathrm{N}$ & $\mathrm{p}$ (McNemar's test) \\
\hline \multirow[t]{3}{*}{ Unhealthy diet } & Without history of diabetes & 15.4 & 12.9 & 2461 & 0.008 \\
\hline & Diabetes since 2008 & 13.8 & 10.0 & 261 & 0.212 \\
\hline & Diabetes since 2003 & 8.8 & 8.2 & 376 & 0.885 \\
\hline \multirow[t]{3}{*}{ Physical inactivity } & Without history of diabetes & 31.7 & 35.6 & 2444 & 0.001 \\
\hline & Diabetes since 2008 & 34.0 & 46.3 & 259 & 0.002 \\
\hline & Diabetes since 2003 & 46.1 & 46.6 & 371 & 0.934 \\
\hline \multirow[t]{3}{*}{ Smoking } & Without history of diabetes & 20.6 & 19.5 & 2163 & 0.198 \\
\hline & Diabetes since 2008 & 16.3 & 14.5 & 221 & 0.627 \\
\hline & Diabetes since 2003 & 13.4 & 12.8 & 329 & 0.832 \\
\hline \multirow{3}{*}{$\begin{array}{l}\text { Heavy alcohol } \\
\text { consumption }\end{array}$} & Without history of diabetes & 6.6 & 8.5 & 1235 & 0.035 \\
\hline & Diabetes since 2008 & 7.4 & 14.9 & 121 & 0.064 \\
\hline & Diabetes since 2003 & 13.8 & 10.2 & 167 & 0.327 \\
\hline
\end{tabular}

*Persons who answered the questions about particular habit in both 2003 and 2008

TABLE 3

PERCENTAGE OF PARTICIPANTS ACCORDING TO THE PREVALENCE OF UNHEALTHY LIFESTYLE HABITS IN 2003 AND 2008

\begin{tabular}{ccccccc}
\hline \multirow{2}{*}{$\begin{array}{c}\text { Number } \\
\text { of unhealthy } \\
\text { habits (0-4) }\end{array}$} & \multicolumn{3}{c}{$2003(\%)$} & & \multicolumn{3}{c}{$2008(\%)$} \\
\cline { 2 - 7 } & Healthy & DM & DM & Healthy & DM \\
2008 & 2003 & DM & 2003 \\
\hline 0 & 43.9 & 50.0 & 40.2 & 42.6 & 36.9 & 40.3 \\
1 & 41.7 & 34.7 & 44.4 & 42.6 & 45.6 & 49.4 \\
2 & 12.0 & 14.0 & 15.0 & 11.4 & 13.1 & 10.3 \\
3 & 1.9 & 1.3 & 0.5 & 2.8 & 4.4 & 0 \\
4 & 0.5 & 0 & 0 & 0.5 & 0 & 0 \\
\hline
\end{tabular}

the study, the prevalence of physical inactivity has risen dramatically and is comparable to that in "old« diabetics, albeit their older age. Due to the nature of the study, it is hard to distinguish whether the physical inactivity, a known risk factor for development of diabetes, was the predecessor to the development of diabetes, or alternatively, whether those who were diagnosed with diabetes worsened their physical activity further. The healthy group has also shown a rise in prevalence of physical inactivity, although less dramatic, probably attributed to aging and lesser mobility.

Unhealthy diet was the least prevalent in the group with previously diagnosed DM, in both points of measure. It must, however, be taken into consideration that habits related to nutrition that were investigated in our study are less comprehensive than the overall recommendations for persons with diabetes, and are hardly the measure of adherence to recommendations for proper nutrition in persons with diabetes.

Prevalence of smoking was also the lowest in old DM group, with prevalence being lower than previously published ${ }^{28}$, and practically identical to data from CroDiab -
Croatian National Diabetes Registry ${ }^{29}$. The lower percentage of smokers in our study could probably be attributed to older age of participants. The prevalence of smoking did not change significantly during the study.

In 2003, already diagnosed diabetics had significantly higher rates of heavy alcohol consumption, with rates comparable to those from CroDiab registry ${ }^{29}$. The groups of newly developed diabetics had the highest rate of heavy alcohol consumption in 2008, with this finding being viewed as a possible risk factor for development of diabetes in previous studies ${ }^{30}$.

Comparing the groups according to number of unhealthy habits of each participant indicates that, again, the group of newly developed diabetes showed worsening of lifestyle habits, while the group that remained diabetes-free did not change.

A recent study from $\mathrm{USA}^{31}$ suggested worsening of healthy lifestyle pattern during the last 18 years, with decreases documented in physical activity, consumption of fruits and vegetables, and increase in body mass index. The percentage of respondents adhering to all 5 of lifestyle habits investigated (including smoking and moderate alcohol consumption) has fallen from 15 to $8 \%$ in the period of this study. Individuals with a history of diabetes were no more likely to be adherent to a healthy lifestyle than diabetes-free individuals. Our study shows a similar pattern, with the finding of more prononunced worsening of healthy lifestyle habits in people who will develop diabetes, which further predisposes them to potentially avoidable complications of diabetes.

The latest yearly report of CroDiab indicates that only 26.6 percent of persons with diabetes have good glycemic control ( $\mathrm{HbA} 1 \mathrm{c}<6.5 \%)$, with $84.8 \%$ being overweight or obese (BMI $\geq 25 \mathrm{~kg} / \mathrm{m}^{2}$ ) and mainly not reaching target values of other modifiable risk factors (lipids, blood pressure, etc. $)^{29}$.

Limitations of our study include the follow-up rate of the survey and the self-reported nature of diabetes sta- 
tus. The strenghts of the study include its large sample size, and the fact that it is the first follow-up survey of this magnitude in Croatia.

In this follow-up survey of lifestyle habits the striking features are the high prevalence of physical inactivity in persons with diabetes and rising prevalence in those who developed diabetes during study. With the established effects of activities directed towards diet and physical activity, both in prevention and management of diabetes, the high prevalence of physical inactivity in diabetes warrants urgent public health-oriented actions. Especially, the emphasis should be made at systematic rather than periodic activities and a multi-sector approach to- wards creating a physical activity-friendly environment. Subgroup with potentially large benefits of increased, regular physical activity are persons with diabetes, and they should be constantly re-educated about the importance of every-day physical activity as the simple and effective way of improving diabetes-related outcomes.

\section{Acknowledgements}

This manuscript is prepared within the project of the Ministry of Science, Education and Sports, Grant \# 108-1080135-0264.

\section{R E F E R E N C E S}

1. SHAW JE, SICREE RA, ZIMMET PZ, Diabetes Res Clin Pract, 87 (2010) 4. - 2. TUOMILEHTO J, LINDSTROM J, ERIKSSON JG, VALLE TT, HAMALAINEN H, ILANNE-PARIKKA P, KEINANEN-KIUKAANNIEMI S, LAAKSO M, LOUHERANTA A, RASTAS M, SALMINEN V, UUSITUPA M, N Engl J Med, 344 (2001) 1343. - 3. PEREIRA MA, KARTASHOV AI, EBBELING CB, VAN HORN L, SLATTERY ML, JACOBS DR, JR., LUDWIG DS, Lancet, 365 (2005) 36. - 4. YUSUF S, REDDY S, OUNPUU S, ANAND S, Circulation, 104 (2001) 2746. - 5 KRISKA AM, SAREMI A, HANSON RL, BENNET PH, KOBES S, WILLIAMS DE, KNOWLER WC, Am J Epidemiol, 158 (2003) 669. - 6. AHIMA RS, J Clin Invest, 121 (2011) 2076. - 7. MANSON JE, RIMM EB, STAMPFER MJ, COLDITZ GA, WILLETT WC, KROLEWSKI AS, ROSNER B, HENNEKENS CH, SPEIZER FE, Lancet, 338 (1991) 774. 8. MANSON JE, NATHAN DM, KROLEWSKI AS, STAMPFER MJ, WILLETT WC, HENNEKENS CH, JAMA, 268 (1992) 63. - 9. MALIK VS, POPKIN BM, BRAY GA, DESPRES JP, WILLETT WC, HU FB, Diabetes Care, 33 (2010) 2477. - 10. ATTVALL S, FOWELIN J, LAGER I, VON SCHENCK H, SMITH U, J Intern Med, 233 (1993) 327. - 11. ZAVARONI I, BONINI L, GASPARINI P, DALL'AGLIO E, PASSERI M, REAVEN GM, Am J Cardiol, 73 (1994) 904. — 12. BALIUNAS DO, TAYLOR BJ, IRVING H, ROERECKE M, PATRA J, MOHAPATRA S, REHM J, Diabetes Care, 32 (2009) 2123. - 13. POLJIČANIN T, PAVLIĆ-RENAR I, METELKO Ž, Coll Antropol, 35 (2011) 829. - 14. BATTY GD, SHIPLEY MJ, MARMOT M, SMITH GD, Diabet Med, 19 (2002) 580. — 15. BATTY GD, KIVIMAKI M, SMITH GD, MARMOT MG, SHIPLEY MJ, Diabetes Care, 30 (2007) 2388. — 16. Clinical Guidelines Task Force, Global guidelines for type 2 diabetes. Brussels: International Diabetes Federation; 2005 (accessed 21.7.2011.). Available from: URL: http://www.idf.org/webdata/
docs/IDF\%20GGT2D.pdf. - 17. American Diabetes Association: Standards of medical care in diabetes - 2010 (Position statement). Diabetes Care. 2010; 33(Suppl.1): S11-S61. - 18. GREEN AJ, BAZATA DD, FOX KM, GRANDY S, Int J Clin Pract, 61 (2007) 1791. - 19. MAGAS S, POLJICANIN T, SEKERIJA M, AJDUKOVIC D, METELKO Z, CAR N, KERN J, Coll Antropol, 33 Suppl 1 (2009) 115. - 20 IDF Atlas. 4th ed. Brussels: International Diabetes Federation, 2009 (accessed 10. 6.2011.). Available from URL: http://www.diabetesatlas.org/content/prevalence-estimates-diabetes-mellitus-dm-2010. - 21. METELKO Z, PAVLIC-RENAR I, POLJICANIN T, SZIROVITZA L, TUREK S, Diabetes Res Clin Pract, 81 (2008) 263. - 22. VULETIC S, POLASEK O, KERN J, STRNAD M, BAKLAIC Z, Coll Antropol, 33 Suppl 1 (2009) 3. - 23. IVIČEVIĆ-UHERNIK A, VULETIĆ S, KERN J, DECKOVIĆ-VUKRES V, MIHEL S, ERCEG M, PRISTAŠA I, Coll Antropol, 36 (2012) suppl 1. 3. - 24. KERN J, STRNAD M, CORIC T, VULETIC S, BMJ, 331 (2005) 208. - 25. KNOWLER WC, BARRETT-CONNOR E, FOWLER SE, HAMMAN RF, LACHIN JM, WALKER EA, NATHAN DM, N Engl J Med, 346 (2002) 393. - 26. KING DE, MAINOUS AG, 3RD, CARNEMOLLA M, EVERETT CJ, Am J Med, 122 (2009) 528. - 27. MYKKANEN L, KUUSISTO J, PYORALA K LAAKSO M, Diabetologia, 36 (1993) 553. - 28. SCHIPF S, SCHMIDT CO, ALTE D, WERNER A, SCHEIDT-NAVE C, JOHN U, STEVELING A, WALLASCHOFSKI H, VOLZKE H, Diabet Med, 26 (2009) 791. - 29 Analiza podataka CroDiab registra za 2010. godinu; p. 7. Available from: URL: http:// www.idb.hr/CDN_2010_ukupni_20110510x.pdf System Requirements: Adobe Acrobat. - 30. WANDELL PE, DE FAIRE U, HELLENIUS ML, Nutr Metab Cardiovasc Dis, 17 (2007) 598. - 31. KING DE, MAINOUS AG, CARNEMOLLA M, EVERETT CJ, Am J Med, 122 (2009) 528.

\section{M. Šekerija}

Croatian National Institute of Public Health, Rockefellerova 7, 10000 Zagreb, Croatia e-mail: mario.sekerija@hzjz.hr

\section{PROMJENE U ŽIVOTNIM NAVIKAMA OSOBA SA ŠEĆERNOM BOLEŠĆU U PETOGODIŠNJEM VREMENSKOM RAZDOBLJU: CROHORT STUDIJA}

\section{S A $\check{Z}$ E T A K}

Prevalencija šećerne bolesti je u porastu u cijelom svijetu, te se procjenjuje da u 2010. na svijetu živi 285 milijuna osoba s dijabetesom, uz još 344 milijuna s poremećenom tolerancijom glukoze. Glavni rizični čimbenici za nastanak šećerne bolesti i razvoj kroničnih komplikacija uključuju debljinu, nezdravu prehranu i tjelesnu neaktivnost. Cilj ovog istraživanja bio je usporediti prevalencije nezdravih načina ponašanja kod osoba koje nemaju šećernu bolest, kod osoba koje će razviti šećernu bolest u idućem petogodišnjem periodu (novi DM) i kod onih koji već imaju dijabetes (stari DM) 
te istražiti promjene rizičnih ponašanja kroz petogodišnji period između dvaju ispitivanja. Istraživanje je bilo dio CroHort studije, presječne studije koja je 2003. i 2008. godine istraživala zdravstveni status, kvalitetu života i korištenje zdravstvenih usluga. Rizična ponašanja bila su definirana kao nedostatak tjelesne aktivnosti, nezdravi način prehrane, pušenje i pretjerana konzumacija alkohola, a dijabetički status potvrđen je odgovorom na pitanje »Imate li povišen šećer?«. U obje grupe sa šećernom bolešću (stari DM i novi DM) rizični čimbenik s najvišom prevalencijom bila je tjelesna neaktivnost (46,7 i 33,7\% u 2003, 46,8 i 46,3\% u 2008), pa pušenje (12,1\% i 14,6\%, 12,7\% i 14,4\%), nezdrava prehrana (8,8 i 13,8\%, 8,2 i 10,0\%) pa pretjerana konzumacija alkohola (11,1\% i 6,0\%, 7,8\% i 13,8\%). Osobe koje nisu imale dijabetes imale su višu prevalenciju pušenja i nezdrave prehrane, a nižu prevalenciju tjelesne neaktivnosti i pretjerane konzumacije alkohola. Osobe koje su razvile šećernu bolest su u razdoblju prije i neposredno nakon dijagnoze se počele značajno manje kretati i izjednačile se s osobama koje već imaju razvijen dijabetes. S obzirom da je prevalencija tjelesne neaktivnosti u obje skupine alarmantna, potrebno je inzistirati na implementaciji i provedbi edukativnih programa o važnosti tjelesne aktivnosti, usmjerenih ka osobama pod rizikom od razvoja šećerne bolesti i već postojećim, naročito novodijagnosticiranim bolesnicima. 